Georgia State University

ScholarWorks @ Georgia State University

1985

\title{
The Demise of Officer Involvement in Soldiers Sport During the American Civil War
}

Lawrence W. Fielding

William T. Weinberg

University of Louisville

Brenda Pitts

Georgia State University, bpitts@gsu.edu

Richard A. Fee

Follow this and additional works at: https://scholarworks.gsu.edu/kin_health_facpub

Part of the Kinesiology Commons

\section{Recommended Citation}

Fielding, L. W., Pitts, B. G., Fee, R.A. \& Weinberg, W.T. (1985, December) The Demise of Officer Involvement in Soldiers Sport During the American Civil War. Canadian Journal of History of Sport, Vol. 16 (2), p. $72-$ 86.

This Article is brought to you for free and open access by the Department of Kinesiology and Health at ScholarWorks @ Georgia State University. It has been accepted for inclusion in Kinesiology Faculty Publications by an authorized administrator of ScholarWorks @ Georgia State University. For more information, please contact scholarworks@gsu.edu. 
THE DEMISE OF OFFICER INVOLVEMENT IN SOLDIERS' SPORT DURING THE AMERICAN CIVIL WAR

\author{
by \\ Lawrence W.Fielding \\ William T. Weinberg \\ Brenda G. Pitts \\ Richard A. Fee \\ University of Louisville
}

During the American Civil War a few officers in the Army of the Potomac became involved in organizing sport for soldiers. ${ }^{1}$ They had ulterior motives. In each instance officers intended to use sport to improve soldier morale, assuage despondency and doubt, and to overcome homesickness. ${ }^{2}$ officers chose sport because they believed that sport entertainment had the capacity to create excitement, excitement that drew men's minds off immediate problems and left a generalized "good feeling" 3 among the men. Once officers had assigned a use value to sport, they began to consider ways to maximize sport's usefulness as a morale booster. To this end officers attempted to organize sport to produce the greatest entertainment for the greatest number. ${ }^{4}$ Their experiment, begun in the fall of 1861, continued periodically during 1862, and reached major proportions during the winter camp at Falmouth, Virginia in 1863. Between January 1, 1863 and April 18, 1863 officers produced six major sport festivals. ${ }^{5}$ Each festival drew between ten and twenty thousand soldiers. After Falmouth the experiment ended abruptly.

Officers organized in specific ways for specific reasons. Their plans and administrative efforts derived from notions about the rank and file as spectators and as participants. These notions were clearly wrong. Beneath the 
obvious problems of organization and administration that were created by officers incomplete understanding about the soldier community's demand for sport involvement lay a deeper misunderstanding. Officers assumed that the rank file would willingly abdicate positions as organizers (producers), allowing officers to formally subjugate leisure actions for productive reasons. This assumption was not entirely wrong. Initially, officers did formally subsume soldier's sport making it an abstract and a concrete tool to meet morale and entertainment needs. The problem was that a certain section within the soldier society would not relinquish control over their sport unless their personal demands for active participation were met. When officers made organizational and administrative mistakes that prevented maximum participation, soldier organizers wrestled control away from the original planners, restructuring organization to meet their own needs. The transfer of control did not always occur smoothly; sometimes officers fought back. At these times the disruptions, the injuries, the loss of control alarmed officers. In the end officers concluded that it was best to let soldiers organize their own fun.

Typically, soldiers organized and administered their own sport. ${ }^{6}$ Officers merely watched. Even massed sport, the periodic snowball battles, rabbit chases, and horse races that drew large crowds of participants and occasionally of spectators as well, originated within the soldier community. ${ }^{7}$ An informative general example of this process, what caused it, and how it worked was the Christmas Day footrace held at Falmouth in 1862 that made Riley Tanner a celebrity.

Riley Tanner represents a particular class of soldiers, men not opposed to officer involvement in the organization of sport, but men who demanded the opportunity to participate as often and as long as they desired. Tanner 
was city bred; he grew up in Scranton, Pennsylvania. After a minimum commitment to public school education, he graduated into the work force relatively early in life. When the war broke out in 1861, Tanner had been in the labor force nearly a decade, six of those years as a railroad mechanic; he had a steady job and family responsibilities. Although the war for the union was important, it was at first remote. Tanner did not enlist immediately because he had other pressing responsibilities. ${ }^{8}$ In August of 1862 when Robert E. Lee and the Confederate Army threatened to invade the North, Tanner enlisted. Two weeks later, a member of the "Railroad Guards," Company "I," 132nd Pennsylvania, he marched to Antietam Creek. The 132nd Pennsylvania became part of the veteran Gibralter Brigade. The veterans greeted the new unit reservedly, acceptance required the test of battle. At Antietam, along the Sunken Road near the Roulette Farm House, Riley Tanner, age 24, and the railroad workers fought their first battle. ${ }^{9}$ Their test of courage, bravely begun, ended in embarrassment when a Confederate cannon shell leveled a long row of bee hives near where the soldiers waited to fight. The men ran in all directions, chased by angry bees, brigade and regimental officers powerless to stop the rout. ${ }^{10}$ Three months later, at Fredericksburg, they redeemed themselves, marching in closed ranks up the hill towards the Stone Wall, where Confederates, lined four and five deep and flanked by massed cannon, waited to open fire. ${ }^{11}$ Twelve days later the survivors celebrated Christmas.

Christmas Day had its drawbacks but ended in excitement. The men of the 132nd, experiencing their first Christmas away from home and families, within sight of a battlefield that could only be described as a devastating Union loss, had little to celebrate. Dinner consisted of boiled rice and molasses, hardtack, and stewed dried ap 
les. ${ }^{12} \mathrm{~A}$ whiskey ration, a gill per man, did little to brighten enthusiasm. ${ }^{13}$ In the afternoon the men organized a footrace with the neighboring 4th New York. A group of Pennsylvania soldiers had been roaming around in the morning looking for something to do. They stumbled across a group of soldiers in the 4th New York practicing their sprinting. Unimpressed, the Pennsylvanians chanted, "He is not much of a runner."14 Challenge followed immediately. The Pennsylvanians hurried back to camp to spread the news of the challenge. Large numbers of soldiers got involved spreading news, joining and conducting sprint trials. ${ }^{15}$ Riley Tanner emerged as champion. The commotion caused by the challenge and the speed trials alerted men from other units. Nearly the whole division gathered, lining both sides of the track with a solid wall of men. ${ }^{16}$ Tanner, "running like a frightened deer," beat the 4th New York's champion by a dozen feet. A furor followed. The Pennsylvanians, hailing Tanner as hero, carried him triumphantly through all the company streets, shouting and bragging as Christmas ended in excitement. ${ }^{17}$

There are elements in the above example that provide insights into both the success and the failure of officer involvement in organized sport. First, the footrace derived from an impromptu challenge. A group of soldiers looking for action found another group of soldiers at play. They devised a means of getting in on the fun. Second, the challenge led to a spree of hastily organized sprint trials that allowed everyone who cared a chance to participate as much as they wanted. Even if defeated a solder could run again. He might not be declared champion, but he could continue to race, searching for someone he could beat. Beyond this, soldiers could and did participate as news spreaders, sprint trial consultants and judges, braggers, and opinion setters, and each felt some degree of 
importance, a part of the event with a stake in the outcome. Third, in lieu of a central organization controlling the search for a champion, soldiers administered several separate organized sprint trials. These small pockets of organization permitted maximum participation for both sprinters and administrators. Finally, officer observers, although aware of the sprint trial process, did not observe the actual administration of the speed trials. Instead, they witnessed the final race between Tanner and the 4 th New York champion. They did not distinguish between spectator and participant; rather, they concluded that the soldiers enjoyed themselves, that the excitement took men's minds off immediate problems, and that sport improved morale whether soldiers played or watched. Officers realized that the quest for champion had been inefficiently administered. This realization was perceptive. Indeed, it is possible that Riley Tanner may not have been the fastest runner in the 132nd Pennsylvania. His emergence as sprint trial winner could merely have been a consequence of his desire to continue racing even when defeated. Put another way, Tanner won because he gradually wore down the opposition. Officers aware of such possibilities concentrated on streamlining the sprint trial process, assuming that soldier organized trials were inefficient because soldiers did not know how to organize effectively. Consequently, when officers organized sport for soldiers, they focused on administrative efficiency and chose sports that large numbers could watch. Early efforts centered around Thanksgiving and Christmas holidays and were regimental affairs. The 1861 Christmas Day celebration organized by Colonel Edward Cross for the 5th New Hampshire was typical.

Cross's original intent was merely to provide some excitement for his soldiers on Christmas morning, leaving 
them free to do as they pleased for the rest of the day. ${ }^{18}$ Although a stern disciplinarian, a man noted for his hot temper when breaches of military conduct occurred, Cross empathized with his men. ${ }^{19}$ The 5th New Hampshire's ranks were dominated by mechanics and small farmers, men with little or no public education, men like Riley Tanner who joined the work force relatively early in life. Most of them were family men, and typically they left good jobs and families behind when they enlisted. The average age in the regiment was twenty-six. 20 They joined the war only when Bull Run convinced them that victory demanded their personal attention. Cross realized that for such men holidays were difficult times breeding thoughts of home and loved ones. To assuage homesickness and despondency, he purchased a pig to be let loose at ten o'clock Christmas morning. ${ }^{21}$ Regimental officers convinced Cross to expand the format to include more activities. Cross added a five hundred yard footrace with the best two of three heats to decide the winner, a wrestling match, and a jumping contest. For each athletic contest cross awarded cash prizes for first and second place finishers. The greased pig chase continued as the final activity. Cross planned the whole affair to be finished before noon. ${ }^{22}$

Nothing went as Cross planned. The footraces consumed almost three hours. The wrestling match did not finish until nearly three o'clock. The greased pig chase, the intended climax of the day, had to be switched from last to third event. The porker was captured much sooner than anticipated. The jumping contest, the new last event, was anticlimatic. Like the other athletic events, the jumping contest took more time than Cross had planned; it ended after dark. ${ }^{23}$

Colonel Cross's inability to administer sport 
effectively within a given time frame derived from two specific though interrelated causes. First, numbers created the problems that frustrated Cross's attempt to organize soldier's sport. There were too many people who wanted to run, or to wrestle or to jump, or to chase the greased pig. Conventional wisdom neither predicted such an occurrence nor provided insights into how to deal with it. The greased pig chase is a case in point. Cross planned to conduct the chase inside a hollow square formed by the soldiers of the regiment. ${ }^{24}$ This was not a bad idea. If the soldiers maintained their positions, the pig would be unable to break completely free. It would be forced to run around inside the square and would eventually tire, making it an easy target for the chasers. The problem with this arrangement was that Cross did not designate which soldiers would be allowed to do the chasing. Instead of a few soldiers rushing after the pig, it appears that the hollow square collapsed around the animal. Soldiers from all sides made a mad dash for the prey. Forty year old private Patrick Rowen reached the pig first. ${ }^{25}$ His hold on the porker was broken by soldiers charging from different directions. Despite collisions and grease, the soldier mob caught the pig, knocking him off his feet and falling on him, the sure weight of numbers preventing further struggle. ${ }^{26}$ The administration of the greased pig chase reflected the same fundamental organizational problems that plagued the footrace, the wrestling match and the jumping contest. There was too little planning for too many soldiers.

The failure to anticipate the number of probable participants resulted in a second problem. Cross lost direct control over the sporting event and the actions of soldier players. Once an event got started, there was no good way of stopping it. The wrestling match is an 
excellent example. Cross had no idea about the actual number of soldiers desiring to wrestle. He apparently thought that most soldiers would rather watch. Consequently, he gave no thought or consideration to how he would handle wrestleoffs. Self-declared winners simply proceeded to wrestle other self-declared winners until everyone had had enough activity, and there were only two men left. ${ }^{27}$ Cross lost control, in part, because he had not planned effectively for the numbers he had to deal with. There was another reason. When Cross's plans proved ineffective, the soldiers took over, administering the fun in much the same way that soldiers in the 132nd Pennsylvania organized the speed trials that led to the emergence of Riley Tanner as champ. Hence, poor planning and large numbers conspired, forcing an administrative breakdown; in an attempt to save the fun soldiers resorted to less centralized methods of administration, forcing Cross to relinquish his jurisdiction over sport.

There were obvious lessons to be gleaned from Cross's attempt to organize and control sport for the soldier community, but officers understood these lessons in incomplete ways. For example, officers learned from experiments like Cross's that better organization was essential. The problem was the officers linked organization to spectators not participants. ${ }^{28}$ Even when the end result, improved morale, appeared to be successful, officers misunderstood the cause. Soldiers at sport appeared to be having a good time. Cross and other officers linked this appearance to a general good feeling among the men, concluding that sport was a viable alternative to common morale problems such as despondency and doubt. ${ }^{29}$ This conclusion by itself was not bad. However, Cross did not comprehend that the good feelings derived from active participation.30 soldiers watching the activity wanted to 
join; they wanted to feel good too. Officers aware of the use value of sport as morale booster desired to maximize sport's effects, but they concluded that these effects accrued equally to spectators and participants. Instead of planning to allow maximum participation for the greatest number of soldiers, officers concentrated on ways of producing excitement for large numbers of spectators. Even elaborate planners like J.H. Hobart Ward and Thomas Francis Meagher failed to understand that maximum participation predicated intelligent organization.

The 1863 New Year's Day sport festival, planned by J.H. Hobart Ward and his staff, paid close attention to spectator enjoyment. ${ }^{31}$ The entertainment included a wide menu of events designated to specific time blocks and organized for special areas to insure maximum viewing pleasure. Soldiers cleared a large, relatively flat area in front of division headquarters on which they built a primitive stadium. In front of the stadium they constructed a racetrack with hurdle and flat jumps. Inside the race track they established areas for mule races, footraces, feats of strength and agility, boxing and wrestling matches, burlesque cockfights and set up a wheel of fortune and a greased pole climb. Space for each of these events was necessarily restricted, but each designated area could be easily viewed from the grandstands. 32 To make events progress efficiently, Ward assigned officers to administer each event. The 38th New York was given the task of welcoming and seating guests and for providing overall crowd control. ${ }^{33}$ Invitations were sent to the different units in the division as well as to other units encamped in the vicinity, "To attend the entertainment. ${ }^{34}$ Prize money was raised among the officers of the division and a one o clock starting time was set for the commencement of the activities. ${ }^{35}$ Ward and his staff excelled at arrangements 
for spectator pleasure and convenience.

Time and space, the two variables that Ward manipulated in favor of anticipated large crowds of watchers, conspired to cause problems when enthusiastic participants arrived on the scene. The one $0^{\prime}$ clock starting time meant in effect that there would be only four or at most five hours of actual play time before darkness made watching difficult. This restriction, requiring several events to be run at the same time, was further complicated by limited space and the belief that certain events, because of their spectator appeal, ought to be run separately. Hence, Ward was required to sequence events on the basis of time, space, and anticipated spectator interest and to do so with a tangible efficiency that kept everything moving. The first event, the hurdle race, came off smoothly, but the races that followed were interrupted by spectators pushing onto the track in an attempt to join the fun. ${ }^{36}$ Exactly what fun the soldiers were trying to join is unclear. They may have desired to actually participate in the horse races. They may have misunderstood the overall plan for the day. Fearing that they would miss the opportunity to play, they pushed onto the track to get to the wheel of fortune, the greased pole climb, and to see what was going on in the infield. In any event, their forced entrance onto the track and into the infield quickly filled all available space, disrupted organization, and threatened carefully planned sequences. ${ }^{37}$

Despite intricate planning, Ward's efforts to host the New Year's Day sport festival failed. Even though the activities that Ward and his staff planned did in fact run, each had complications. The number of aspiring participants and the lack of foresight about soldier demand for active involvement caused the problems. The sport festival attracted between ten and twenty thousand soldiers. ${ }^{38}$ The centralized infield was not designed for anywhere near that 
many participants. It would have been better to have spread things out to allow greater play space. The events Ward planned were not designed to accommodate enthusiastic players but to entertain spectators. The wheel of fortune, for example, permitted only one soldier to participate at a time but allowed many to watch and to be amused by the ludicrous failures of others. ${ }^{39}$ Organizers made no attempt to limit or control the number of participants. Only for the footraces did they announce any restrictions on who could play; the footraces were closed to men in the Pennsylvania Reserve. ${ }^{40}$ When massive numbers of soldiers demanded access to the ranks of participation, planning suffered and organization disintegrated. The race track and the infield became a milling mass of men interested in performing not watching. The officers of Ward's staff assigned to run the events did in fact adjust. When the time designated for their particular event was up, they stopped and left the field. ${ }^{41}$ When this happened, the soldier community took over and ran the event as they pleased. This disrupted the administration of events that were supposed to follow. Consequently, organization and administration continued to deteriorate. Before the day was over soldiers had succeeded, once again, in wresting the control of sport away from the original planners.

In Cross's and Ward's attempts to organize sport for soldiers a general trend emerges. Both officers intended to use sport to improve soldier morale. When they organized sport, they took control away from the soldier community, a community used to planning and administering its own fun. Both Cross and Ward took control because they wanted to maximize sport's use value. ${ }^{42}$ Through proper organization and efficient administration, they believed that they could extend the entertainment power of sport to greater numbers of soldiers. Initially, the soldier community acquiesced, 
permitting the takeover of their leisure by officers. However, when officer planning and administration failed to accommodate solider interest in participation, the soldier community first disrupted administrative efforts and then gradually took over the control of sport. In the above examples neither Cross or Ward attempted to prevent or even contest the takeover. They simply relinquished the field to the common soldier. ${ }^{43}$ Thomas Francis Meagher and the staff officers of the Irish Brigade did not give up control so easily.

The planning and organization that preceded Meagher's St.Patrick's Day celebration of 1863 accentuated the errors that Cross and Ward made earlier. Nearly every minute of the entire day was planned. ${ }^{4}$ Committees were assigned to organize every detail. The day was to begin with a Mass at 8:00 a.m.for which the brigade built a chapel. A steeplechase track, two and one-half miles long, was constructed with hurdles and ditched fences. The track crossed two natural rivers which brigade engineers reconstructed, making them uniformly thirty feet wide and between four and six feet deep. Along the course judges' stands and a clerk of the course stand were built. A large grandstand was erected at the finish line. The horse races were to begin at eleven o'clock, followed by a special luncheon at one o'clock. In the afternoon sports for noncommissioned officers and privates were planned. ${ }^{45}$ Meagher organized footraces, weight casting contests, a soaped pig chase, hurdle races, a wheelbarrow race, sack races, and an Irish dance contest. The evening was to be devoted to theatrical entertainments including recitations, songs, and toasts. ${ }^{46}$ Meagher and his committees, aware of the time and space problems caused by so many events, planned to control participation by 
limiting the number of players in specific events. ${ }^{47}$ To accomplish this end they expediently assigned certain soldiers to act as participants, 48 believing somehow that other soldiers would understand that they were not to participate and would therefore be content merely to watch. Meagher and his staff apparently never considered what the soldier community might do when they saw the fun and were informed that they were not to be included beyond the act of watching.

Although the day began smoothly, it ended turbulently and abruptly. The first sport event, the Grand Steeplechase, open only to officers in the Irish Brigade, came off very well. The trouble began during the second steeplechase, the "Race for All Comers." 49 The race was designed to allow officers in other units the opportunity to compete in a steeplechase. ${ }^{50} \mathrm{~A}$ race for all comers meant to the rank and file that anyone who wanted to race would be given the opportunity to indulge their desires. Consequently, some soldiers tried to join the race. ${ }^{51}$ Fortunately for the organizers the race began before the would-be participants could secure their mounts. ${ }^{52}$ It was also fortunate that the organizers had planned for the winner to be declared after only one heat. At one o'clock Meagher announced that there would be a short intermission before the afternoon sports began. Thinking that everything was running smoothly, Meagher and his staff adjourned to the luncheon feast with their special guests. ${ }^{53}$

Attempting to adjourn so large a crowd before it had the opportunity to do anything was not one of Meagher's better ideas. When Meagher and his staff vacated the racing field, the private soldier took control. Horses of every shape and description entered the field, ridden by all manner of horsemen. ${ }^{54}$ The race track 
became a mass of men and horses, racing everywhere and in every direction, without regard for life or limb. This continued, despite injury and death, until Meagher and his staff returned and attempted to regain control of the sport events. By this time things had gone too far. The soldier community was unwilling to submit again to officer control. The soldier organized horse races continued despite the fact that officers began to administer other events in the same areas. ${ }^{55}$ Indeed, many soldiers viewed the planned for events as mere sideshows to their own horse races. ${ }^{56}$ Just as the last footrace began a fight broke out among the men. Joseph Hooker, commander of the Army of the Potomac, whether perturbed or frightened, decided that the only way to regain control of the situation was to send the soldiers back to their respective units. ${ }^{57}$ Hooker's orders brought the athletic events to an abrupt halt.

Meagher's elaborate plans, like the plans of Ward and Cross before him, were thwarted by rambunctious soldiers bent on joining the fun. To his credit, Meagher realized the need to limit participation. However, Meagher, his staff, and his committees had not developed an effective plan to limit participation. Instead of spending all his time building facilities, Meagher would have been better off devoting that time to conducting trial heats and elimination contests to cut down the size of the field of active participants. This process could have effectively included soldiers as organizers and administrators in much the same way that the 132nd Pennsylvania did when choosing a sprint champion. This idea did not occur to Meagher. His actions were expedient. He apparently did not consider what might happen when soldiers discovered that they would not be allowed to participate. The idea of telling twenty thousand soldiers to wait while he and his staff had lunch informs about Meagher's basic misconceptions regarding the soldier 
community, its thirst for active participation and what it was likely to do when officer organizers prevented fun.

Thomas Livermore, an officer in the 18th New Hampshire, could have told Meagher what would happen. In 1861 Livermore had been a noncommissioned officer in the 5th New Hampshire. ${ }^{58}$ He had been a part of the Christmas Day celebration that Colonel Cross had planned.59 He knew how the soldier community would react when official plans for sport went awry. Livermore observed the Irish Brigade's celebration on St. Patrick's Day, 1863. A devoted adherent of horse racing, Livermore had been disappointed when he couldn't enter "the race for all comers" because his horse, borrowed from Adjutant Dodd, arrived late. Later, Livermore decided that he had been fortunate: "I might have been brought off the field with a broken collar bone, or worse, had it not been that Dodd failed to reach the field in time with his horse." ${ }^{60}$ After the first race had been completed, foot soldiers took control of the track, sponsoring additional races without the advantage of rules or common sense. ${ }^{61}$ There were thousands on the field. Everyone who cared to play mustered a horse and joined the fun. The track, already muddy from the first race, became a slippery quagmire. The racing continued, unrestrained by any power, until two horsemen, charging in opposite directions, collided. Both men were killed as were both horses. ${ }^{62}$ The enlisted men, enthusiastic, eager to join the fun, took control of the horse races when Meagher and his staff relinquished the field. The lack of centralized control made the horse race a free-for-all, a place unfit for man or beast. The footraces that followed, Meagher's bid to regain control, ended prematurely because the common soldiers would not relinquish the control of sport a second time without a fight.

Livermore's observations provide three important 
insights into the problems officers experienced when they tried to take control of soldier sport. ${ }^{63}$ First, Livermore's description of the St. Patrick's Day celebration provides insight into the process of the soldier takeover. As Livermore watched the gradual disintegration of officer control, other observers watched with him. Not everyone pushed onto the field to participate. Sport enthusiasts took control. Furthermore, they took control gradually by creating small pockets of organization. This was why there were so many horse races in different directions at different distances. This was why the track appeared to be a milling mass of humanity and horseflesh. As the small pockets of organization broadened, drawing larger and larger numbers into the role of active participant, all semblance of official control disappeared. Meagher may not have been able to regain control simply because by the time he returned to the field there were too many organizers already operating to permit a return to a single centralized administration.

Second, Livermore provides important clues about who the sport enthusiasts that took control of sport actually were. Livermore's experience with the 5th New Hampshire provided important insights. The soldier takeover of st. Patrick's Day sport was more than merely a response to poor planning and organization. When Cross's organization of the Christmas Day celebration proved faulty, soldiers took over because men, like Riley Tanner, were used to organizing and administering their own fun. They acquiesced to official involvement in sport administration only to the extent that officers planned effectively. When demands for participation were not met, soldiers took control and administered sport for maximum play time and enjoyment. Tanner and the soldiers in the 5th New Hampshire shared similar backgrounds. Most of them entered 
the work force relatively early in life by necessity. They were men short on formal education and long on work experience. They had steady jobs before the war, usually as skilled workers. They enlisted late because they had more pressing responsibilities at home. In general, they were men who had experienced a modicum of success in life as a result of their own drive and initiative. They were used to taking work related orders from bosses or employers. The notion that officers could or should take control of soldiers' leisure activities, even if such a development was in the soldiers' best interest, had not occurred to them. When it happened, they waited to see if their desire for fun was met. When it wasn't, they took control.

Finally, Livermore provides insights into the probable reasons officers declined to get involved in organizing sport for soldiers after Falmouth. Despite the disruptions, the loss of control, the injuries and the deaths that attended the occurrence of the sport festivals, officers still believed that sport could be used to improve morale. ${ }^{64}$ However, the problems officers experienced in organizing sport for their charges had important consequences. In general, officers concluded that the disadvantages outweighed the advantages. Officers like Livermore believed that organizing sport for soldiers was not necessary. The men who disrupted sport, men who caused the problems, were the active participants. They were the soldiers who derived the greatest benefit from sport. They were the participants who became so engrossed in activity that they forgot immediate problems. This becoming engrossed was also part of the problem. When restrictions were placed in the way of their fun, these enthusiastic participants responded by 
organizing and administering sport on their own irrespective of official plans. The spectators who with Livermore continued to watch were not actively involved and therefore derived less benefit from sport festival. More importantly, the soldiers who did get involved, the ones who disrupted because they desired activity, were the ones who would have organized sport for themselves if officers had not bothered. ${ }^{65}$ Hence, officer involvement in sport only created problems, 66 problems that could easily be avoided by simply letting the soldier community organize and administer its own leisure, just as it had always done.

\section{FOOTNOTES}

1. Relatively few officers organized sport for soldiers. Volunteer officers in the 2 nd and 3rd Corps of the Union Army headed the of principal organizers. There are no general sources. See for specific examples: William Child, A History of the 5th Regiment New Hampshire Volunteers, in the American Civil War, 1861-1865Bristol, NH: R.W. Muss printer 1893), p.41; William Penn Lloyd, History of the First Regiment Pennsylvania Reserve Cavalry(Philadelphia: King and Baird, Printers, p.37; Alonzo H. Quint, The Record of the Second Massachusetts Infantry,

1861-1865 (Boston: J.P. Walker, 1867), pp. 5152; Abner Hard, History o Eighth Cavalry Regiment)Illinois Volunteers during the Great 
Rebellion (Aurora, II: N.P., 1868 , P.57;

Frederick T.Peet, Civil War Letters and Documents (Newport, RI: privately printed, 1917), p.52;

George H. Allen Forty-Six Months with the 4th Rhode Island Volunteers, in the War of 1865 (Providence: J.A.\& R.A.Reid, printers, 1887), P.41; Eugene A. N History of the 44th Regiment, New York Volunteer Infantylin the Civil War 1861-1865 (Chicago: R.R.Donnelley and Sons Company, 1911 , p. 155; Edwin M.Haynes, A History of the 10 Regiment Vermont Volunteers (Lewiston, ME: Published by the Tenth Vermont Regimental Association, 1870), p. 27; Gil A.Hays, Under the Red Patch: Story of the 63rd Regiment Pennsylvania Volunteers, 1861-1864 (Pittsburg: 63rd Pennsylvania Volunteers Regimen Association, 1908), p.175; Edwin B. Houghton, The Campaigns of the 17th Maine(Portland, ME: Short and Loring, 1866), pp.40-41. We have of course not attempted to list every source containing instances of officer involvement in the organization and administration of sport for soldiers.

2. This point is derived from the analysis of reasons contained in the specific sources listed in footnote one. Other references to officer specified reasons can be found in: Oliver Wilson Davis, Life of David B Birney Major General United States Volunteers (Philadelphia: King \& Ba 1867), pp.80-111; Edward K. Gould, Major-General Hiram G.Berry (Rockland ME: Press of the Courier-Gazette, 1899), pp.89-93; William Corby, Memoirs of Chaplain Life (Notre 
Dame, In: Scholastic Press, 1894), p.29.

3. Corby, Memoirs, p. 9; David D.Co"y"gham, The The Irish Brigade and Its Campaigns (Boston: P.Dinahoe, 1869), p. 144; Michael Cavanagh Memoirs of General Thomas Francis Meagher (Worchester, MA: The Messenger Press, 1892), p. 478 .

4. Of the several examples of this the best can be found in: Conyngham, Irish Brigade, pp.14449, 371-83; Davis, Life of Birney, pp. 80-1ll.

5. The six major sport festivals were as follows. January 1 , 1863; March 17 (two); March 27, 1863; April 5, 1863; April 18, 1863. For specific documentation and specifics of each occasion see Lawrence W. Fielding, Sport Along the Road to Appomattox (University of Maryland, doctoral dissertation, 1974 pp.387-456.

6. Fielding, Sport Along the Road to Appomattox, pp. 300-492, specific sport anecdotes.

7. Ibid.

8. Frederick L. Hitchcock, War From the Inside (Philadelphia: J.B. $t$ Company, 1904), pp. 1$51,55-90$.

9. Ibid. This was a bad place for green troops. A lot of men died very short period of time.

10. Ibid. 
11. ibid. Tanner and his comrades attacked Longstreet's position, a heavily fortified, virtually impregnable position. Longstreet

said that from such a position he could hold off 100,000 men.

12. Ibid, pp. 149-51.

13. Ibid. A gill of whiskey is about 4 ounces.

14. Ibid, p. 149.

15. Ibid, pp. 149-51.

16. Ibid. A division is made up of four

brigades (i.e, 12 regiments 12,000 men). This

is the estimate of numbers provided by

Hitchcock. Doubtless, there were many soldiers

watching. However, 12,000 seems too high an estimate.

17. Ibid. Riley Tanner got shot at

Chancellorsville four months later. He never recovered. He died in a Union Hospital shortly after Lee surrendered at Appomattox. 18. Child, 5th New Hampshire, p. 41. Child's description is based upoin the personal records of Captain John R. McCrillis. McCrillis was a private at the time. 19. Child, 5th New Hampshire, pp. 41, 311-14. 20. Ibid. See Complete Roster, Part II, pp. 4212 .

21. Ibid, p. 41. This was Child's opinion. 22. Ibid, pp. 41-2, see McCrillis's account of the celebration plans.

23. Ibid.

24. Ibid. See McCrillis's account.

25. Ibid. Rowen was in the same unit as

McCrillis.

26. Ibid.

27. Ibid. 
28. This point derives from the analysis of specific sources notes 1,2 and 3 .

29. Ibid. See also Child, 5th New Hampshire, p.

41. See also specific references in Child to

Cross's Letter Collection, pp. 19, 21, 31$34,63-67$.

30. Ibid. See specific citations to Cross's letters. It is also important to note that Cross had a great deal of confidence in his soldiers abilities to fight and that he attributed this ability to individual initiative. The same initiative that led soldiers to organize and administer their own sport - or to take over when official plans failed. See also narratives by sergeant Lewis C. Fernald, pp. 102-104 and Captain Janvrin Graves, pp. 104-113.

31. Hays, Red Patch, p. 175; Houghton, 17th Maine, pp. 40-41; New York Herald, Weekly Magazine, 10 January 1863.

32. Ibid. Ward's planning continually focused upon convenience for spectators.

33. Phillipe Regis Denis de Kereden de Trobriand, Four Years with the Army of the Potomac, George K. Dauchy, Trans. (Boston: Ticknor and Company, 1889), p. 155; Marie C. (de Trobriand) Post, The Life and Memoirs of Comte Regis de Trobriand, Major General in the Army of the United States York: E.P. Dutton \& Co., 1910), p. 263. It doesn't appear that Trobriand the commander of the 38th New York, understood what Ward intended by crowd control.

34. Houghton, 17th Maine, pp. 40-41. The invitations said specifically, "To attend the 
entertainment."

35. Ibid. See also Hays, Red Patch, p. 175.

36. Davis, Life of Birney, pp. 80-111; Gould, Hiram G. Berry pp. 89-93; Hays, Red Patch, p.

175; Houghton, 17th Maine, pp. $40 \& 41$

37. Ibid.

38. Ibid.

39. Ibid.

40. Ibid. Exactly why the Pennsylvania reserve were restricted is unclear. Evidence

indicates that it was a sanction designed to prevent Riley Tanner from entering the race. 41. Ibid. Although Ward, Berry and Birney raised several hundred dollars to use as prize money, it was never awarded. The contests were never completely finished. No one seems to know exactly what happened to the money. 42. Ibid. See also footnote 29.

43. Hays, Red Patch, p. 175; Houghton, 17th Maine, pp. 40-41; Child, New Hampshire, p.41. The question that remains unanswered here is why they didn't? Were they too surprised? Did they see the futility in attempting to control so many soldiers? Or, did they realize that they weren't organized enough to control?

44. Conyngham, Irish Brigade, pp.372-B3, is the best single description. See also: Paul Jones, The Irish Brigade New York: Robert B•Luce, Inc., 1969), pp. 164-166; Cavanagh, Thomas Francis Meagher, pp. 478-480;Corby, Memoirs, pp. 140141 .

45. Ibid. 46. Ibid.

47. Ibid. The specific events Meagher planned to control were as follows: Steeplechase, horse 
races, wheelbarrow races, and the sack races. The footrace was 2 mile and the weight casting contests were with weights of between 10 and 14 pounds. Meagher and his staff considered these events to be self-restricting because of distance and techniques involved. The soaped pig chase never came off because Meagher couldn't get a pig.

48. Ibid. This was never announced. Meagher and his organizers did it quietly.

49. Ibid. The race had been advertised to officers only. Private soldiers learned of its existence only when Meagher announced it at the beginning of the program.

50. Ibid. The organizers knew who would participate before the race an. Horsemanship and horse breeding served to limit the field.

51. Thomas M. Aldrich, The History of Battery A, First Regiment Rhode and Light Artillery in the War to Preserve the Union, 1861-1865

(Providence: Snow and Farnham, Printers, 1904), p.171; Hitchcock, War From Inside, pp.200-02; Thomas Leonard Livermore, Days and Events, $1860-$ 1866 Bosston: Houghton and Mifflin Company, 1920), pp.186-188.

52. Ibid.

53. Conyngham, Irish Brigade, pp. 372-83

54. Hitchcock, War from the Inside, pp. 200-202;

Livermore, Days and Events, pp. 186-188; Thomas Francis Galwey, The Valiant Hours: Narrative of "Captain Brevet", an Irish-American in the Army of the Potomas, W.S. Nye, ed. Harrisburg, PA: Stackpole, 1961), pp. 78-9. 55. Ibid. 56. Ibid. 
57. Ibid. There are conflicting reports regarding Hooker's reason for sending the men back to their units. Some soldiers thought the reason was because Hooker, aware that the Battle of Kelly's ford was going on, wanted to have the Army ready. I doubt that this was the reason. Kelly's Ford was a cavalry battle. It had been going on all day. Hooker was aware of it. Indeed, he had planned it. Furthermore, the lith and 12th Corps were already in a position to support the Union Cavalry if the need developed. Beyond this, by 4 o'clock the battle was largely finished. The cavalry was on way back.

58. Livermore, Days and Events, pp. 23-37.

Livermore was $1^{\text {st }}$ Sergeant of Company $K$.

59. Ibid, p. 37. Livermore provides interesting insights into Cross and the soldiers in the 5th New Hampshire.

60. Ibid, pp. 186-88.

61. Ibid. I am paraphrasing Livermore's account. 62. Ibid.

63. Ibid. Livermore's insights are dispersed throughout the book Most of them do not deal directly with soldiers' sport but provide a basic understanding of who these people were and how they normally acted and reacted.

64. Many sources document this point. Two of the better examples, Hays, Red Patch, p. 175;

Conyngham, Irish Brigade, p. 383.

65. This point derives from analyzing the units in which soldier organized their own sport with the units that created the problems during officer organized sport. The units were the same in 
most instances.

66. Officer involvement brought large groups of soldiers together one spot at one time. 